\title{
FORENSIC ACCOUNTING SERVICES IN ENGLISH LOCAL GOVERNMENT AND THE COUNTER-FRAUD AGENDA
}

\author{
Mohd Hadafi Sahdan, Christopher J. Cowton and Julie E. Drake
}

\section{ABSTRACT}

Fraud is a growing challenge for English local government, yet the resources and support local authorities (LAs) have available to prevent, detect and investigate it are limited. Forensic accounting services (FAS) provided by external specialist private sector firms, particularly those undertaking mandatory external audit, might be one solution. Findings of a questionnaire survey suggest, however, that existing English LA users are not all convinced. Nevertheless, better awareness and understanding of what FAS have to offer, perhaps through case studies of successful implementation, would be a valuable contribution to helping local government enhance its counter-fraud capabilities and make informed decisions about how best to meet the increasingly complex fraud challenge.

\section{INTRODUCTION}

English local authorities (LAs), like public sector organizations in many countries, are experiencing an increasing tension between the pressure for good quality administration and cost-cutting (Hood and Dixon, 2016). At the same time, they face a growing threat from fraud, which is on the rise in the UK (Levi et al., 2017), fuelled in particular by the twin sources of digital technology and organized crime (Levi, 2017), alongside increased contracting out of services. Addressing fraud in LAs has been subject to two iterations of a strategy to address fraud in local government, in 2011 and 2016. The second of these - Fighting Fraud \& Corruption Locally: The Local Government Counter Fraud and Corruption Strategy, 2016-2019 (henceforth Fighting Fraud) (CIPFA, 2016) - is adamant about the need for a 'tougher response' (p.6). It speaks of the need to 'transform' counter-fraud and corruption performance, requiring innovation to 'keep ahead of fraudsters' (CIPFA, 2016, p.4). However, the abolition of the Audit Commission in 2015 (Tonkiss and Skelcher, 2015) and other changes have probably weakened the ability of LAs to tackle fraud. The 'flawed architecture' of counter-fraud entities in the UK (Button, 2011) and the lack of 'coherence, co-ordination, common approaches and a commitment of resources' (Doig, 2018, p. 147) mean that the rhetoric and recommendations of the various strategies that have been proposed over the years fall short of providing the conditions for actual operational implementation to take place on the ground (Doig, 2018).

Whatever the precise cost of fraud to LAs (see Levi and Burrows, 2008) and the problematic strategic support context (Button, 2011), spending money on the development of capacity and expertise to combat the threat of fraud might ordinarily be a sound business decision; 'invest to save', as Fighting Fraud (CIPFA 2016, p. 5) terms it. However, in a period of austerity for public services it is difficult to increase, or even maintain, expenditure on any area of activity, especially when it is not a core one mandated by central government (CIPFA, 2016). New spending commitments, such as taking on more counter-fraud staff, are difficult to justify in a tightly cash-constrained context. Nevertheless, in such an environment there might still exist opportunities for LAs to buy-in specialist forensic accounting services (FAS) from external specialist private sector firms, including those providing mandatory external audit services, which offer an increasingly recognized set of specialized skills (Hegazy et al., 2017). This could be on an ad hoc basis when budgets allow (e.g. when the end of the financial year is in sight), not only to produce future savings but also, perhaps, to increase the likelihood of recovering monies fraudulently obtained. However, the option of using FAS does not receive any attention in Fighting Fraud or literature that addresses the fraud challenge faced by LAs. Drawing on the findings of a questionnaire survey, the aim of this article is therefore to examine the scope for LAs to use externally-sourced FAS as one element of their response to the counter-fraud agenda. 
The article is structured as follows. First, the issues facing LAs and the key features of current thinking about fraud, including FAS, are outlined. Second, the empirical research method for the survey is briefly described. Third, the findings of the survey are presented. The final section offers conclusions and implications.

\section{THE FRAUD CHALLENGE FOR LOCAL AUTHORITIES}

\section{Fraud}

Fraud and corruption cost local government dear, taking many forms and occurring across a wide range of operations and sometimes targeted across multiple LAs. CIPFA, a professional association which is responsible for the training and accreditation of the majority of LA internal auditors, as well as providing a range of toolkits and services to LAs, undertakes an annual fraud survey. Its 2018 survey (CIPFA, 2018) indicates that:

- the total estimated value of fraud detected or prevented by local authorities in $2017 / 18$ was $£ 302 \mathrm{~m}$, $f 34 \mathrm{~m}$ less than the previous year's total;

- the number of frauds detected or prevented rose to 80,000 from the 75,000 cases found in $2016 / 17$;

- the number of serious or organized crime cases doubled to 56 in 2017/18;

- the amount lost to business rates fraud increased significantly to $f 10.4 \mathrm{~m}$ in $2017 / 18$ from $f 4.3 \mathrm{~m}$ in 2016/17;

- Blue Badge fraud (relating to parking for disabled users) also increased by $f 3 m$ to an estimated value of $£ 7.3 \mathrm{~m}$ for cases prevented/detected in 2017/18;

- the three greatest areas of perceived fraud risk are procurement, council tax single person discount (SPD) and adult social care; and

- the four main types of fraud (by volume) that affect local authorities are council tax, housing, Blue Badge fraud and business rates.

Indeed, it was the first iteration of the strategy for LAs - the 2011 Local Government Fraud Strategy that warned that both opportunity and pressure were being intensified at local level:

Radical changes are underway to how local services are to be delivered. The next few years will see major reforms to the welfare system, policing and local government. The change of emphasis from local government being a provider to a commissioner of services changes the risk profile of fraud, as well as the control environment in which risk is managed. More arm's length delivery of services by third parties in the voluntary and not-for-profit sector and personal control of social care budgets, for example, will mean that more public money is entrusted to more actors, whilst the controls the local authority previously exercised are removed or reduced. Without new safeguards, preventing, detecting and investigating fraud will become more difficult. All of these changes are happening against a backdrop of depressed economic activity in which the general fraud risk tends to increase. Harder times tend to lead to an increased motivation to defraud by some clients, suppliers and employees who are feeling the squeeze. (National Fraud Authority, 2011, p. 6)

\section{Context and Change}

The concerns raised by the 2011 strategy came at a time of significant change. The Localism agenda has had a significant impact in terms of driving down local government expenditure and requiring changes to the level and delivery of functions and services: 'local government reforms... emphasise 
local responsibility, the abolition of targets and reduction of planning powers. They cut budgets substantially and encourage private providers to contract for the whole range of local services' (TaylorGooby and Stoker, 2011, p. 9). The changes have increased the sub-contracting to the private sector, both for-profit and not-for-profit organizations, of many services traditionally provided by LAs themselves - a development that is typical of New Public Management (Alonso et al., 2013). Procurement fraud is a major consequential risk:

It has been estimated that procurement fraud costs local government in the region of $£ 876$ million a year making it the largest single area of financial loss to fraud in local government. This is fraud - and other related criminal activity - that occurs in connection with the local authority supply chain. It occurs throughout the procurement cycle and is particularly prevalent in the contract management phase. (LGA, 2015, p. 2)

Another major factor, which is increasing the number and size of fraud attacks upon LAs, is digital technology. Many types of 'cybercrime' are relatively easy to commit but difficult to address (May and Bhardwa, 2018). Cyberfraud is a growing problem. Digital technology not only creates new points of vulnerability, but also, due to its rapidly evolving nature, places great technical demands upon inhouse staff, who are hard-pressed to remain up-to-date. Moreover, organized crime has not been slow to take advantage of the opportunities that the shift to digital offers (May and Bhardwa, 2018) and, as previously noted, the number of serious or organized crime cases doubled to 56 in 2017/18 according to CIPFA's annual fraud survey. Furthermore, although not all cyberfraud is across borders (Levi et al., 2017), international criminal groups have become seriously involved. Not only is there likely to be an imbalance between the sophistication of the criminal groups and the resources of the target, but the criminals are able to exploit the diffuseness and opaqueness of the Internet, as well as legislative and enforcement weaknesses in different jurisdictions, to evade punishment.

Nevertheless, although there can be practical challenges, both the 2011 and 2016 fraud strategies for local government promote the principle of addressing fraud from cradle to grave - prevent, detect, investigate and recover. The former argued:

Enforcement covers the investigation, punishment and recovery of assets and funds. Punishing fraudsters acts as a powerful deterrent. Where fraud is discovered the full range of sanctions should be deployed, including civil, disciplinary and criminal action. Effective enforcement requires that local authority investigators have the professional skills (operating within a professional code), appropriate powers and access to specialist support to undertake their duties. (National Fraud Authority, 2011, p. 27)

Much of that specialist support used to come from the Audit Commission, the national public body which included the District Audit Service (DAS). The external audit regime began in 1844 (see Coombs and Jenkins, 2002) with national oversight and monitoring introduced by the 1982 Local Government Finance Act through the establishment of the Audit Commission. It took a continuing and proactive stance on the need to identify and address financial loss as well as ensure appropriate governance arrangements (see Public Audit Forum, 2001). It assumed responsibility for the existing statutory public external audit arrangements which became its Audit Practice. DAS provided mandatory external audit services to local authorities using in-house and contracted private sector firms, setting the standards for audits which included specific audit days to assess each council's arrangements to prevent and detect fraud and corruption.

The Audit Commission issued Public Interest Reports (PIR; legally-privileged reports which commented on unacceptable or potentially illegal conduct). It funded and facilitated the Good Conduct and 
Counter Fraud Network which promoted anti-fraud work among all council external auditors, including private sector firms. It was a designated body for whistleblowing under the Public Interest Disclosure Act (PIDA). It had mandated powers for the collection and publication of annual fraud and corruption data (published in the annual Protecting the Public Purse reports). It used its powers to set up and lead a national annual data-mining and matching initiative - the National Fraud Initiative (NFI) - from information provided by both public and private sectors, whose results were sent as 'risk' matches to be reviewed as potential frauds, overpayments and errors in public expenditure. It issued guidance on areas such as governance, probity and working with private and voluntary sector partners, the outcomes of which it reviewed and monitored, often with prescriptive assessments of what should be done. Furthermore, its comprehensive performance assessment was intended to ensure robust procedures were delivered within what it termed the softer characteristics of leadership and standards.

Although the curtailment of the Audit Commission's roles had been signalled, as part of the government's Localism agenda, in a 2008 Conservative Party paper which proposed a narrower focus in ensuring 'the propriety of local government's spending and to investigate complaints' (Conservative Party, 2008, p. 18), the 'decision to close the Commission outright was unanticipated' (Sandford, 2016, p. 15). Analysis of the closure announcement suggests that the nature and presentation of the decision to wind up the Audit Commission by 2014 quickly shifted the discourse from the Audit Commission's abolition to 'the low politics of technical debate about the new audit system' (Tonkiss and Skelcher 2015, p. 875; see also Timmins and Gash, 2014), albeit offset by concerns about the lack of attention to future ownership of its anti-fraud responsibilities. These included the Association of Chartered Certified Accountants' warnings that different functions could risk 'potentially being fragmented across different bodies in an uncoordinated and inconsistent way' (House of Commons Communities and Local Government Committee 2011, Ev93) and those of the Committee on Standards in Public Life about the inherent robustness of the new arrangements (see Lawton and Macaulay, 2013, p. 78).

Under the 2014 Local Audit and Accountability Act, councils may appoint their own external auditors, after a transitional period where contracts had been bid for and awarded to private sector firms by the Audit Commission. The contracts are managed through the Public Sector Audit Appointments Limited (PSAA), an independent company limited by guarantee incorporated by the Local Government Association in 2014. PSAA continued to be responsible for appointing most councils' auditors for the audit of the accounts for 2017/18 and, it was hoped - at least by the DCLG (Department for Communities and Local Government) - that councils would continue the existing arrangements from 2018/19 onward rather than secure their own arrangements.

\section{Responses}

This new context had been anticipated by the 2011 strategy: 'local authorities and central government will need to look to design new arrangements for the new conditions. That will most likely require the greater sharing of counter fraud and audit resources, the creation of a new control framework and new institutional arrangements, building on the existing shared counter fraud infrastructure' (National Fraud Authority, 2011, p. 18). For LAs, the fraud challenge comprises not only mitigating the threat through strategies for prevention, but also how to respond through detection, investigation and recovery - especially with the reduction in policing resource for fraud (see Gannon and Doig, 2010). One response has been counter-fraud services (CFS), which originated within the NHS, though they have often been reported as under-resourced and 'more susceptible to cuts in their budgets' (Button, 2011 , p. 254). However an LA's response to fraud is organized, it may comprise many possible elements, including developing an anti-fraud culture, understanding and measuring fraud risk, and managing and learning from incidents (see Samociuk and lyer, 2010). Various activities or stages are involved. As Fighting Fraud notes, to acknowledge the existence of fraud is a critical first step; and 
understanding fraud risks and committing support and resource are vital to a robust anti-fraud response. Steps need to be taken to prevent fraud, but with determined and ingenious fraudsters and an ever-evolving context, attempts must also be taken to detect fraud, perhaps by making better use of information and technology. Once the possibility of a fraud has been identified, it is then important to investigate and, if appropriate, to pursue the fraudsters with a view to recovering losses and seeking the perpetrators' punishment, in collaboration with the police - if they are willing to commit resources to this.

Thus fraud may be tackled by in-house CFS in collaboration with the internal audit function, which itself may be provided in-house or out-sourced in some way. However, LAs report that their staff do not always have the skills or training to tackle fraud (CIPFA, 2016), and in a period of constrained resources, it is difficult for local government to build its capacity. Nor may it rely, as it did with the Audit Commission, on the capacity and terms of reference of the external auditor (see National Audit Office, 2019a; Sandford, 2019); at a time when the risk profiles of many LAs have increased, so have their concerns about the contribution of external audit (see National Audit Office, 2019b). Nevertheless, many of the firms that provide external audit to local government offer additional forensic accounting services (FAS), usually in a separate team. For example, the 'Big Four' audit firms list 'Forensic and Financial Crime Team' (Deloitte), 'Forensic Services' (PwC), 'Forensic and Integrity Services' (EY) and 'Forensic' (KPMG) on their websites. FAS could be a valuable source of further help to local government in tackling fraud, providing extra capacity and additional skills.

\section{The Role of FAS}

The precise definition of FAS is still a matter for debate and, indeed, tends to depend on context (Huber and DiGabriele, 2014) and on a particular author's purpose and perspective, but Van Akkeren and Buckby's description is a good starting point:

To investigate, resolve and minimise fraud, forensic accounting practitioners are consulted for their specific skills and expertise. Their work includes investigating financial inconsistencies, analysing evidence, interviewing potential suspects and preparing expert reports in their attempt to identify the person or persons responsible for the crime. (Van Akkeren and Buckby, 2017, p. 384)

While the latter element of Van Akkeren and Buckby's description emphasizes detection and investigation, the idea of minimizing fraud also points to the role that forensic accountants can play in preventing fraud, as well as recovery. It should also be noted, as Apostolou \& Crumbley (2005) highlight, that there are important differences between the role of a forensic accountant and an auditor; an auditor determines compliance with auditing standards and considers the possibility of fraud, whereas a forensic accountant has a single-minded focus on fraud and similar irregularities, as contracted with the client. Moreover, while the authors above use the term forensic accounting (and we will continue to do so, in line with common practice), it is a multidimensional field of activity, less focused on accounting than might be suggested by its name. FAS teams tend to comprise individuals with complementary skills rather than a common base of specialist skills (Hegazy et al., 2017). Although the field in the UK is dominated by professionally qualified accountants and many accounting firms offer FAS, such firms also employ staff with other qualifications and skills. Furthermore, some law firms also offer FAS, and there exist specialist firms too.

Forensic accounting is a growing area of practice that has come to the fore since the first years of the $21^{\text {st }}$ century (Hegazy et al., 2017; Chew, 2017). The public sector in general is recognized as a major client for FAS providers (Hegazy et al., 2017). LAs certainly tend to be experienced in using consultancy services in general (Kipping and Saint-Martin, 2005), and the use of FAS might have a role to play in 
helping them meet the increasing threat of fraud. FAS can not only increase general capacity at critical times (perhaps when a major fraud is under investigation), but also provide expertise that is not possessed in-house. This article therefore seeks to answer the following two research questions:

1. What is the current position regarding the use of forensic accounting services by local government?

2. What are the prospects for the future use of forensic accounting services by local government?

These questions were addressed as part of a questionnaire survey of English LAs. The design and conduct of the survey are explained in the next section.

\section{THE SURVEY DESIGN}

The questionnaire was designed to address the objectives of a research framework developed from the academic and practitioner literature. Four of the questionnaire's ten sections are utilized here: local authority characteristics; use of, and satisfaction with, FAS; perceptions about FAS; and intention to use FAS in the future. A pre-test of the questionnaire was given to academicians (one with experience as a local authority finance director) and postgraduate students, and refined accordingly. A sample of 50 internal auditors, chief executives and internal auditors was used to pilot the questionnaire in April 2014. The responses received did not necessitate significant changes to the questionnaire and so are included in the final sample for analysis.

The survey was sent, with a subsequent reminder, from June to November 2014, to all 353 LAs in England. FAS were defined as 'services provided by an external party such as accounting firms that applies specialized investigative skills and techniques in detecting any existing fraud and proactively setting up fraud prevention systems'. In order to increase the response rate, the questionnaire was sent to a named person where possible. Since all LAs have an internal audit function, the head of internal audit was targeted. However, the name of only a third of heads of internal audit could be found on websites (119 out of 353 , or $33.7 \%$ ), so questionnaires were also sent to chief executives and directors of finance, whose details were generally easier to discover. The composition of the sample and responses is shown in Table 1.

Table 1. Sample and responses

\begin{tabular}{|c|c|c|c|c|c|c|c|c|c|}
\hline \multirow[t]{2}{*}{$\begin{array}{l}\text { Type of local } \\
\text { authority }\end{array}$} & \multirow[t]{2}{*}{ Number } & \multirow{2}{*}{$\begin{array}{l}\text { Question- } \\
\text { naires } \\
\text { sent }\end{array}$} & \multicolumn{5}{|c|}{ Completed questionnaires received } & \multicolumn{2}{|c|}{$\begin{array}{c}\text { Estimates of } \\
\text { response rate }\end{array}$} \\
\hline & & & $\begin{array}{l}\text { Internal } \\
\text { Auditor } \\
\text { (IA) }\end{array}$ & $\begin{array}{l}\text { Counter } \\
\text { Fraud } \\
\text { Manager }\end{array}$ & $\begin{array}{l}\text { Director } \\
\text { of } \\
\text { Finance }\end{array}$ & Other & Total & $\begin{array}{l}\text { Overall } \\
\text { (\%) }\end{array}$ & $\begin{array}{l}\text { IA } \\
\text { (\%) }\end{array}$ \\
\hline English County & 27 & 81 & 14 & 3 & 2 & 0 & 19 & 23.5 & 51.9 \\
\hline $\begin{array}{l}\text { Metropolitan } \\
\text { Borough }\end{array}$ & 36 & 108 & 11 & 0 & 1 & 0 & 12 & 11.1 & 30.6 \\
\hline English Unitary & 56 & 168 & 14 & 4 & 1 & 3 & 22 & 13.1 & 25.0 \\
\hline $\begin{array}{l}\text { London } \\
\text { Borough }\end{array}$ & 33 & 99 & 7 & 1 & 2 & 2 & 12 & 12.1 & 21.2 \\
\hline English District & 201 & 603 & 45 & 8 & 17 & 4 & 74 & 12.3 & 22.4 \\
\hline Total & 353 & 1,059 & 91 & 16 & 23 & 9 & 139 & 13.1 & 25.8 \\
\hline
\end{tabular}

The response rates from different sorts of LA were broadly comparable, except that county councils appear to have been more responsive. There is no particular reason to suppose that their answers will

\footnotetext{
${ }^{1}$ Estimates of response rate: Overall = total responses divided by number of questionnaires sent; $I A=$ number of responses received from internal auditors divided by the number of local authorities.
} 
be systematically different, but the difference in response rates should be noted. As might be expected, responses were most frequently from internal auditors (65.5\% of responses), followed by directors of finance (16.5\%) and CFS managers (11.5\%). The latter category had not been directly addressed, so they must have been passed the questionnaire by someone else; there are a few similar cases in the 'Other' response category in Table 1.

Sending to three categories increased the probability of obtaining a response from a particular LA, but because anonymity was promised to respondents in order to encourage their response and to discourage socially desirable response bias, it is not possible to know the extent to which multiple responses were received. The response rate therefore needs to be expressed as a possible range rather than a single figure. On the one hand, the overall return of all questionnaires was $13.1 \%$ $(139 / 1059)$, but the response rate from internal auditors amounted to $25.8 \%$ (91/139). Although a higher response rate would have been welcome, this represents a very respectable outcome for a survey of this type. Nevertheless, any conclusions and recommendations will bear in mind that responses were received from a minority of LAs - about a quarter at most.

\section{THE SURVEY FINDINGS}

As background, the questionnaire asked about the provision of internal audit and CFS. Table 2 summarizes the responses.

\section{Overview}

Table 2. Provision of internal audit and counter-fraud services

\begin{tabular}{|l|c|c|}
\hline \multicolumn{2}{|l|}{ Number of Local Authorities } & $\%$ \\
\hline Current provision of internal audit services & \\
\hline Maintained in-house & 82 & 59.0 \\
\hline Joint/shared services & 27 & 19.4 \\
\hline Partially outsourced & 8 & 5.8 \\
\hline Fully outsourced & 22 & 15.8 \\
\hline Total & 139 & 100.0 \\
\hline Current provision of in-house counter-fraud services (CFS) & 70.5 \\
\hline Has in-house CFS & 98 & 29.5 \\
\hline No in-house CFS & 41 & 100.0 \\
\hline Total & 135 & \\
\hline
\end{tabular}

Table 2 shows that three-fifths of internal audit services are maintained wholly in-house. However, this means that two-fifths involve some sort of external provision, which suggests that a significant proportion of LAs are comfortable with working with outsiders in this area - which might be of relevance to the provision of FAS. Dedicated CFS exist in more than two-thirds of LAs, but that still leaves almost a third that do not have such services and thus might be ripe for using FAS - although perhaps they are not taking fraud as seriously. Moreover, in the vast majority of cases where there is a CFS team, fewer than ten members of staff are employed, which suggests limited capacity and is consistent with Button's (2011) comment that there tends to be at most a 'handful' of staff.

\section{Experience of using FAS}

Respondents were asked whether their LA had experience of using FAS. Table 3 summarizes the findings. 
Table 3. The use of FAS by local authorities

\begin{tabular}{|l|l|l|l|l|l|l|l|l|l|l|l|l|l|}
\hline & \multicolumn{2}{l}{$\begin{array}{l}\text { English } \\
\text { County }\end{array}$} & \multicolumn{2}{l|}{$\begin{array}{l}\text { Metropolitan } \\
\text { Borough }\end{array}$} & \multicolumn{2}{l|}{$\begin{array}{l}\text { English } \\
\text { Unitary }\end{array}$} & \multicolumn{2}{l|}{$\begin{array}{l}\text { London } \\
\text { Borough }\end{array}$} & \multicolumn{2}{l|}{$\begin{array}{l}\text { English } \\
\text { District }\end{array}$} & \multicolumn{2}{l|}{ Total } \\
& $\mathrm{n}$ & $\%$ & $\mathrm{n}$ & $\%$ & $\mathrm{n}$ & $\%$ & $\mathrm{n}$ & $\%$ & $\mathrm{n}$ & $\%$ & $\mathrm{n}$ & $\%$ \\
\hline FAS & 7 & 36.8 & 2 & 16.7 & 3 & 13.6 & 4 & 33.3 & 10 & 13.5 & 26 & 18.7 \\
\hline None & 12 & 63.2 & 10 & 83.3 & 19 & 86.4 & 8 & 66.7 & 64 & 86.5 & 113 & 81.3 \\
\hline Total & 19 & 100 & 12 & 100 & 22 & 100 & 12 & 100 & 74 & 100 & 139 & 100 \\
\hline
\end{tabular}

Table 3 shows that less than a fifth (18.7\%) of the total respondents used FAS. English County Councils and London Borough Councils were found to be the most likely to use FAS. The relatively high usage by LBCs (but still only a third of them) might reflect a response to the number of public housing sector and benefit claimants - both high risk areas for fraud - or the capital's international links and hence accessibility to overseas criminals. Overall, usage of FAS does not appear to be widespread, especially if users are thought more likely to respond to the survey than non-users. Nevertheless, it is interesting to see what users do.

Respondents were asked what different types of FAS had been used within the last year. Complementing the earlier definitional discussion, the list of options was constructed from a deskbased review of FAS provider websites. Table 4 presents the responses of the 26 FAS users.

Table 4. Types of FAS used

\begin{tabular}{|l|l|}
\hline Type of forensic accounting service & Used in past year \\
\hline Fraud risk management & 8 \\
\hline Fraud detection & 7 \\
\hline Asset tracing and recovery & 7 \\
\hline Fraud investigations & 7 \\
\hline Digital forensic including data mining, data imaging and recovery & 6 \\
\hline Reviewing current counter-fraud procedures & 5 \\
\hline Fraud prevention system & 5 \\
\hline Fraud training & 5 \\
\hline Assessing and improving internal control system & 5 \\
\hline Developing regulatory compliance strategies & 4 \\
\hline Litigation support and expert witness & 2 \\
\hline Damage or loss quantification & 2 \\
\hline Prosecution cases & 2 \\
\hline &
\end{tabular}

As can be seen, no one service dominates, and none is used by more than a third of users - or less than $7 \%$ of the total respondents. There is a mix of interventions, from the strategic or preventative, through to investigation and prosecution. Some of these services are likely to complement what LAs, especially those with their own in-house CFS, can do to some extent themselves, while others are likely to bring more specialist input (e.g. training, digital work or expert witness).

Finally, it should be noted that FAS were sourced from a variety of providers. The 26 respondents who reported using FAS can be broken down as follows: 8 used only Big Four accounting firms (KPMG, PwC, 
Deloitte and EY); 18 used only other firms; and 4 used both. Thus the Big Four do not dominate the market.

To sum up, it appears that usage of FAS, whether provided by Big Four accounting firms or others, is not widespread. Various services are used, but no particular area of activity dominates. However, while the level of usage is currently relatively low, the questionnaire attempted to gain an insight into possible future developments, given that the FAS appear generally to be increasing in importance.

\section{The Future of FAS in LAs}

In their study of forensic accounting providers, Hegazy et al. (2017) found that the market was expected to grow. This might suggest that the usage of FAS by LAs will build on the position indicated by the survey findings reported so far. However, any increase will likely be influenced by the intentions and attitudes of present users - currently only a minority of LAs. In the questionnaire survey, users of FAS were asked about whether they thought their LA would continue to do so. The first line of Table 5 summarizes their views.

Table 5. Future intentions regarding the use of FAS

\begin{tabular}{|l|l|l|l|l|l|l|}
\hline Future intention & $\begin{array}{c}\text { Definite } \\
\text { intent to } \\
\text { Use }\end{array}$ & $\begin{array}{c}\text { Some intent } \\
\text { to Use }\end{array}$ & Don't know & $\begin{array}{c}\text { Little intent } \\
\text { to Use }\end{array}$ & $\begin{array}{c}\text { No intent to } \\
\text { use }\end{array}$ & Total \\
\hline $\begin{array}{l}\text { Local authorities that } \\
\text { have used FAS }\end{array}$ & 2 & 13 & 7 & 3 & 1 & 26 \\
\hline $\begin{array}{l}\text { Local authorities that } \\
\text { have not used FAS }\end{array}$ & 28 & 57 & 21 & 6 & 1 & 113 \\
\hline $\begin{array}{l}\text { Total number of } \\
\text { respondents }\end{array}$ & 30 & 70 & 28 & 9 & 2 & 139 \\
\hline
\end{tabular}

Four respondents believed they had little or no intention of continuing to use going forward, and only a small majority had some intention to do so $(15 / 26=57.7 \%)$. Of course, this might just reflect a genuine lack of confidence in predicting the future, but it is not unreasonable to suggest that if the use of FAS had proved a resounding success, with users becoming convinced of their value and the likelihood of being able to make a convincing business case, some clearer indications of intention to use again might have been anticipated. Responses to a question about satisfaction with FAS are illuminating in this respect.

Table 6. Satisfaction with FAS

\begin{tabular}{|c|c|c|c|c|c|c|}
\hline \multirow[b]{2}{*}{ Type of provider } & \multicolumn{6}{|c|}{ Satisfaction level } \\
\hline & $\begin{array}{l}\text { Very } \\
\text { dissatisfied }\end{array}$ & Dissatisfied & Uncertain & Satisfied & $\begin{array}{l}\text { Very } \\
\text { satisfied }\end{array}$ & Total \\
\hline $\begin{array}{l}\text { Big Four } \\
\text { accounting firms }\end{array}$ & 1 & 1 & 3 & 3 & 2 & 10 \\
\hline Other providers & 2 & 0 & 4 & 8 & 6 & 20 \\
\hline Total & 3 & 1 & 7 & 10 & 8 & 30 \\
\hline
\end{tabular}

${ }^{a}$ KPMG, PwC, Deloitte and EY

A basic Likert scale is not a precise measurement of the benefits, or net benefits, derived from the use of FAS, but again the findings suggest a lack of enthusiasm, at least where Big Four firms were concerned, with only half of users being at least satisfied. This probably helps to account for the limited intention towards further use of FAS in Table 5. Although the numbers are small, it is interesting to 
note that in three of the four cases where definite dissatisfaction was registered, 'very dissatisfied' was the response, which suggests that some expectations had been severely disappointed.

However, respondents whose LA had not used FAS were also asked about their intentions to do so in the future. Their responses were more favourable than those who had used FAS, with a significant majority $(85 / 113=75.2 \%)$ indicating some possible intention to use (see Table 5). Although there might have been an element of socially desirable response bias on the part of respondents who had not used FAS, there are thus indications that there might be future growth in demand for FAS, which will need to happen if they are going to make a major contribution to helping LAs meet the fraud challenge.

Further insight is provided by Table 7, which summarizes the responses from all 139 respondents to questions about awareness, knowledge of benefits, knowledge of risks, and overall perception of FAS.

Table 7. Overview of attitudes to FAS

\begin{tabular}{|l|l|l|l|l|l|l|}
\hline \multirow{2}{*}{ Statements } & \multicolumn{3}{|l|}{ Extent of agreement (\% of respondents) } \\
\cline { 2 - 7 } & $\begin{array}{l}\text { Strongly } \\
\text { disagree }\end{array}$ & $\begin{array}{l}\text { Disagre } \\
\mathrm{e}\end{array}$ & Neutral & Agree & $\begin{array}{l}\text { Strongly } \\
\text { agree }\end{array}$ & $\begin{array}{l}\text { Total } \\
\text { positive }\end{array}$ \\
\hline $\begin{array}{l}\text { My local authority is } \\
\text { aware of the role of } \\
\text { forensic accounting } \\
\text { services in fraud } \\
\text { detection and } \\
\text { prevention }\end{array}$ & 1.4 & 20.9 & 24.5 & 48.9 & 4.3 & 53.2 \\
\hline $\begin{array}{l}\text { My local authority is } \\
\text { knowledgeable about } \\
\text { the benefits of using } \\
\text { forensic accounting } \\
\text { services }\end{array}$ & 2.9 & 29.5 & 31.7 & 34.5 & 1.4 & 35.9 \\
\hline $\begin{array}{l}\text { My local authority is } \\
\text { knowledgeable about } \\
\text { the risks of using } \\
\text { forensic accounting } \\
\text { services }\end{array}$ & 2.9 & 29.5 & 36.7 & 29.5 & 1.4 & 30.9 \\
\hline $\begin{array}{l}\text { Overall, my local } \\
\text { authority's perception } \\
\text { of forensic accounting } \\
\text { services is positive }\end{array}$ & 0.7 & 12.2 & 64.0 & 19.4 & 3.6 & 23.0 \\
\hline a.e. 'Agree' or 'Strongly agree' & & & & & \\
\hline
\end{tabular}

\section{Overview}

The 2016 Fighting Fraud strategy noted that its 2011 iteration had argued that a 'vital element of any effective counter fraud strategy is the ability of the organisation to call upon competent, professionally accredited counter fraud specialists trained to the highest possible professional standards to investigate suspected fraud' and yet it also noted that since 2011:

Many local authority practitioners reported that the capacity to tackle fraud and corruption was likely to be reduced, or had already been reduced, as a result of austerity-related local authority funding reductions. In many cases practitioners also 
reported that the skilled investigation resource transferred to the Department for Work and Pensions Single Fraud Investigation Service (SFIS) had not been replaced, and some stated that after the SFIS transfer their authority would have no fraud team. (CIPFA, 2016, p. 15)

In such circumstances, externally-sourced FAS could fill that gap, providing both extra capacity and specialist skills. While current external auditors tend to provide a basic, minimal service when compared to what the Audit Commission did, many of those firms also offer FAS - although they might not represent the best value for money and, notwithstanding the attempt to limit the scope of audit in relation to fraud, might find themselves facing a conflict of interest if involved in the investigation of fraud. However, with their knowledge of a particular LA's systems, they might be well placed to offer additional advice in relation to the prevention of fraud, which is often overlooked (Moore and Martin, 2017). Thus, whether provided by their existing auditors, another accounting firm, a law firm or a specialist FAS firm, FAS would seem to offer LAs a valuable complement to their existing, but limited and highly pressured, in-house capabilities. This is particularly the case in relation to digital fraud, which is evolving rapidly and requires specialist skills, especially when the fraud is perpetrated by organized criminal groups.

However, Table 7 suggests that less than a quarter of LAs are really positive about FAS. To some extent, this reflects actual knowledge of FAS, acquired through experience in a limited proportion of cases, but it is striking that almost half of respondents do not agree that their LA is aware of the role of FAS in fraud detection and protection. (This might reflect, or be reflected in, the lack of consideration of FAS in either the 2011 or 2016 strategies.) Thus, while there is evidence of some usage of FAS in the local government sector, it is not unreasonable to suggest that the possible contribution of FAS is probably not something that has been widely considered and thought through. This perhaps reflects the funding pressure that local government is under, but both prevention and recovery offer the prospect of financial benefit, suggesting that carefully targeted and managed use of FAS might have something to offer.

\section{CONCLUSIONS}

Local government is reported to be under-resourced to tackle fraud. Staff have been lost; internal audit is no longer mandated to have fraud as part of planned work; and external auditors, who took over the Audit Commission's audit responsibilities (Tonkiss and Skelcher, 2015), are said to be disinterested in fraud and probity (Doig, 2018) - all at a time when fraud risks are increasing. The Fighting Fraud report (CIPFA, 2016) recognizes that fraud is a major challenge for local authorities (LAs) and makes some useful recommendations, but it does not consider the use of externally-sourced forensic accounting services (FAS), which have seen significant growth and promotion internationally in recent years (Hegazy et al., 2017). In the light of resources and embedded competence falling far short of national rhetoric about tackling public sector fraud in the UK for many years (Doig, 2018), this omission merited empirical examination.

Although the research data has some limitations, it provides a useful first snapshot of the situation. Indeed, following on from Hegazy et al. (2017), which claims to be the first study of FAS in the UK, but with a focus on the provider side, our paper appears to be the first to examine systematically the use of FAS in any sector in the UK. To summarize the answers to our two research questions on the current and future use of forensic accounting services by English local authorities:

1. There is some use of FAS by LAs, but - especially if users are more likely to respond to a survey than non-users - it is currently not widespread. Moreover, previous users seem, overall, to be somewhat ambivalent about the value of FAS. On the other hand, many non-users are 
probably unaware of what is available and how FAS might complement their existing capabilities.

2. There does not seem to be a significant core of enthusiastic pioneers or early adopters that will champion the rapid take-up of FAS across the sector - which would presumably be needed in a period of austerity. While there is some evidence of interest in using FAS in the future, growth is likely to be held back by both limited awareness of FAS and continued financial constraints. This might mean that some 'invest to save' opportunities are missed.

Nevertheless, LAs face a significant threat of fraud, which - because of digital technology and organized crime - is likely to increase in both size and complexity. As Fighting Fraud emphasizes, a tougher response is required. The report also refers to the need for innovation, to keep ahead of fraudsters. However, it does not mention externally sourced FAS provided by professionals who are likely to have specialist expertise that is not necessarily possessed by LAs' in-house CFS team (if there is one) or internal audit staff. It would therefore seem unwise to dismiss the use of outsourced FAS tout court; they have something to offer, as appears to have been discovered by some LAs, according to our findings. In particular, the digital threat is likely to require particular expertise.

Indeed, there was some suggestion in the survey that FAS had not been consciously rejected by many non-users. Perhaps what is needed now is awareness raising across the sector. There is some suggestion that one set of FAS providers - the private sector external auditors that took over from the Audit Commission - are not particularly interested, for whatever reason, in taking on wider roles in relation to fraud and probity (Doig, 2018), so they might not be a strong influence upon awareness. However, the general rise in the profile of FAS is likely to have an effect (Hegazy et al., 2017). What would probably be most effective, though, is the development of a more detailed understanding of the ways in which specific FAS can be profitably employed by LAs; case studies or other accounts of successful implementation would seem to have a role to play here. This would help other LAs to come to a sensible decision about the use of FAS and, where appropriate, to make a satisfactory business case. However, it should be noted that making a business case is currently an area of challenge undermining the 'invest to save' approach to combatting fraud advocated in Fighting Fraud. It is especially difficult in an era of financial conformance (Ferry and Eckersley, 2015), when the principal focus is upon spending alone. Nevertheless, if Fighting Fraud is updated or superseded in time, perhaps it could explicitly consider the case for various types of FAS and, if possible, include reports of successful implementation. While we do not advocate a wholesale rush to use externally-sourced FAS, greater awareness and a better understanding of what they have to offer would surely be a valuable contribution to helping LAs enhance their counter-fraud armoury and make informed decisions of how best to meet the increasingly complex fraud challenge.

\section{REFERENCES}

Alonso, J.M., Clifton, J. and Díaz-Fuentes, D. (2013), Did New Public Management matter? An empirical analysis of the outsourcing and decentralization effects on public sector size. Public Management Review, 17, 5, pp. 643-660.

Apostolou, N. and Crumbley, D.L. (2005), The expanding role of the forensic accountant. The Forensic Examiner, 3, 9, pp. 39-43.

Button, M. (2011), Fraud investigation and the "flawed architecture" of counter fraud entities in the United Kingdom. International Journal of Law, Crime and Justice, 39, 4, pp. 249-265.

Chew, B-L. (Ed.), Forensic Accounting and Finance: Principles and Practice (Kogan Page). 
CIPFA (2016), Fighting Fraud \& Corruption Locally: The Local Government Counter Fraud and Corruption Strategy, 2016-2019 (CIPFA). Available at https://assets.publishing.service.gov.uk/government/uploads/system/uploads/attachment data/file \$503657/Fighting fraud and corruption locally strategy.pdf.

CIPFA (2018), CIPFA Fraud and Corruption Tracker Survey Summary Report 2018 (CIPFA). Available at file:///C:/Users/sbuscjc/Downloads/CIPFA\%20Fraud\%20and\%20Corruption\%20Tracker\%20Summary \%20Report\%202018.pdf.

Conservative Party (2008), Control Shift: Returning Power to Local Communities. Policy Green paper No. 9 (The Conservative Party).

Coombs, H.M. and Jenkins, D.E. (2002), Public Sector Financial Management, Third Edition (Thomson Learning).

Doig, A. (2018), Fraud: from national strategies to practice on the ground-a regional case study. Public Money \& Management, 38, 2, pp. 147-156.

Ferry, L. and Eckersley, P. (2015), Budgeting and governing for deficit reduction in the UK public sector: act three 'accountability and audit arrangements'. Public Money \&Management, 35, 3, pp. 203-210.

Gannon, R. and Doig, A. (2010), Ducking the answer? Fraud strategies and police resources. Policing and Society, 20, 1, pp. 39-60.

Hegazy, S., Sangster, A. and Kotb, A. (2017), Mapping forensic accounting in the UK. Journal of International Accounting, Auditing and Taxation, 28, pp. 43-56.

Hood, C. and Dixon, R. (2016), Not what it said on the tin? Reflections on three decades of UK public management reform. Financial Accountability \& Management, 32, 4, pp. 409-428.

House of Commons Communities and Local Government Committee. 2011. Audit and Inspection of Local Authorities. $4^{\text {th }}$ Report. HC 763 (House of Commons Communities and Local Government Committee).

Huber, D. and DiGabriele, J. A. (2014), Research in forensic accounting - what matters? Journal of Theoretical Accounting Research, 10, 1, pp. 40-70.

Kipping, M. and Saint-Martin, D. (2005), Between regulation, promotion and consumption: government and management consultancy in Britain. Business History, 47, 3, pp. 449-465.

Lawton, A. and Macaulay, M. (2013). Localism in practice: investigating citizen participation and good governance in local government standards of conduct. Public Administration Review, 74, 1, pp. 75-83.

Levi, M. (2017), Assessing the trends, scale and nature of economic cybercrimes: overview and issues. Crime, Law and Social Change, 67, 1, pp. 3-20.

Levi, M. and Burrows, J. (2008), Measuring the impact of fraud in the UK: a conceptual and empirical journey. British Journal of Criminology, 48, 3, pp. 293-318. 
Levi, M., Doig, A., Gundur, R., Wall, D. and Williams, M. (2017), Cyberfraud and the implications for effective risk-based responses: themes from UK research. Crime, Law and Social Change, 67, 1, pp. 77-96.

LGA (2015), Managing the Risk of Procurement Fraud (Local Government Association).

May, T. and Bhardwa, B. (2018), Organised Crime Groups involved in Fraud (Palgrave Macmillan).

Moore, F.H. and Martin, S. (2017), The forensic accountant in practice. In Chew, B-L. (Ed.), Forensic Accounting and Finance: Principles and Practice (Kogan Page) pp. 1-17.

National Audit Office (2019a), Local Auditor Reporting in England 2018. HC 1864 (National Audit Office).

National Audit Office (2019b), Local Authority Governance. HC 1865 (National Audit Office).

National Fraud Authority (2011), The Local Government Fraud Strategy (National Fraud Authority).

Public Audit Forum (2001), Propriety and Audit in the Public Sector (National Audit Office).

Samociuk, M. and Iyer, I; Doody, H. (Ed.) (2010), A Short Guide to Fraud Risk: Fraud Resistance and Detection (Gower).

Sandford, M. (2016), Local Audit in England. Briefing paper 06046 (House of Commons Library).

Sandford, M. (2019), Local Audit in England. Briefing paper 07240 (House of Commons Library).

Taylor-Gooby, P. and Stoker, G. (2011), The Coalition programme: a new vision for Britain or politics as usual? The Political Quarterly, 82, 1, pp. 4-15.

Timmins, N. and Gash, T. (2014), Dying to Improve. The Demise of the Audit Commission and Other Improvement Agencies (Institute for Government).

Tonkiss, K. and Skelcher, C. (2015), Abolishing the Audit Commission: framing, discourse coalitions and administrative reform. Local Government Studies, 41, 6, pp. 861-880.

Van Akkeren, J. and Buckby, S. (2017), Perceptions on the causes of individual and fraudulent cooffending: views of forensic accountants. Journal of Business Ethics, 146, 2, pp. 383-404. 